Research Article

\title{
Quality and Performance Evaluation of Jatropha Oil Blended with Kerosene for Cooking Stoves in Ethiopia
}

\author{
Lake Belete Adamu ${ }^{1,2}$ and Kamil Dino Adem (iD ${ }^{3}$ \\ ${ }^{1}$ Wondo Genet College of Forestry and Natural Resources, Hawassa University, Shashamane, Ethiopia \\ ${ }^{2}$ Ethiopia-Environment, Forest and Climate Change Commission (EFCCC), Addis Ababa, Ethiopia \\ ${ }^{3}$ School of Mechanical and Industrial Engineering, Addis Ababa Institute of Technology, Addis Ababa University, \\ Addis Ababa, Ethiopia \\ Correspondence should be addressed to Kamil Dino Adem; kdadem@gmail.com
}

Received 18 February 2020; Revised 22 July 2020; Accepted 30 July 2020; Published 17 August 2020

Academic Editor: Abdurrahman Saydut

Copyright (c) 2020 Lake Belete Adamu and Kamil Dino Adem. This is an open access article distributed under the Creative Commons Attribution License, which permits unrestricted use, distribution, and reproduction in any medium, provided the original work is properly cited.

\begin{abstract}
In Ethiopia, the majority of rural household uses firewood with three-stone fire for cooking. Due to poor performance of the stove, there are major health issues created by indoor air pollution. To alleviate this problem, various efforts are undergoing such as the use of plant oil as an alternative fuel for cooking. This plant's oils are available in the rural areas with minimal effort and water. In this study, Jatropha oil was blended with kerosene to present it as an alternative fuel for the rural poor in Ethiopia. The blends of varying proportions of Jatropha oil and kerosene were prepared, analyzed, and compared with the fuel properties of kerosene. The viscosity of Jatropha oil was reduced in ranges $86.3 \%$ to $4.5 \%$ by heating the oil from $30^{\circ} \mathrm{C}$ to $100^{\circ} \mathrm{C}$. In order to understand the value of the blended fuel, the blended fuel was used for the evaluation of the performance of a stove for its thermal efficiency and indoor air pollution. Thermal efficiency of the newly designed bio-oil stove (Jatrok stove) was 52-66\% with its specific fuel consumption ranging from 30 to $37 \mathrm{~g} / \mathrm{L}$ and the fire power of the stove ranging from 1398 to 1433 watt using $10 \%$ to $40 \%$ Jatropha oil in the blend. In the case of emission, the Jatrok stove showed 11.5 to 9.5 grams of carbon monoxide (CO) and 352 to 289 grams of carbon dioxide $\left(\mathrm{CO}_{2}\right)$ to boil 2.5 liters of water.The performance of the Jatrok stove using blended fuels was evaluated and compared with other domestic cooking stoves available in Ethiopia, making the stove comparable. A wider dissemination of such kind of plant oil blended with a kerosene-operated stove could reduce the environmental load in addition to lessoning the indoor air pollution in the kitchen.
\end{abstract}

\section{Introduction}

The growing concern on environmental protection and the severe climate change has made the attention on use of alternative energy sources to substitute the fossil fuel. Plant oils as alternative fuels have huge potential to be used as an energy source since they are renewable and could emit significantly less greenhouse gases with improving energy security [1]. Many countries developed energy crops based on the climate conditions of their country. In Ethiopia, Jatropha curcas, castor seed, and palm tree are dominant energy plants cultivated by the government for energy purpose [2]. Jatropha curcas is grouped in the family Euphorbiaceae and has the scientific denomination of
Jatropha curcas L. It is a large shrub which has the maximum height not exceeding 5 meters and has been considered as a potential alternative fuel since it is nonedible and the most promising source of oil [3].

In Ethiopia, despite the opportunities for growing Jatropha as a biofuel crop, some barriers such as technical capacity and low awareness slowed down the utilization of the Jatropha plant oil $[4,5]$. The calorific value of Jatropha oil is about $39.65 \mathrm{~kJ} / \mathrm{kg}$ which is close to the calorific value of kerosene $(43.50 \mathrm{~kJ} / \mathrm{kg})$; however, Jatropha oil has high viscosity $(75.5 \mathrm{cSt})$ which is about 35 -fold that of kerosene $(2.2 \mathrm{cSt})$. This has a major impact on its utilization [6]. Various studies are trying to reduce the viscosity of vegetable oils using different techniques such as blending with 
alcohols or diesel fuels $[7,8]$, heating $[8,9]$, transesterification [10], and microemulsion with solvents (methanol and ethanol) [11]. In other studies for diesel engine applications, the blends of biodiesel with diesel showed lower smoke emissions and particulate matter than diesel fuel [12-17].

In parallel, some attempts have been made to develop cooking stoves for utilizing plant oils as a fuel source. However, the viscosity of plant oil is many times higher than that of kerosene where common wick-type cookstoves are not suitable to use plant oils as the cooking fuel [6]. Therefore, researchers have been focusing on utilization of plant oils on gravity [18] and pressure stoves [19].

In the pressure plant stove, the plant oil evaporates in a vaporizer and emitted through a nozzle to the combustion area and mixed with ambient air and burns. Its power is adjusted with a valve by regulating the fuel flow. It is a complex technology, and expensive [19]. In the gravity stove, the fuel tank is separated from stove, and the fuel is fed under gravity force. Placing the fuel tank above the burner helps to overcome the resistance encountered by the fuel during flow through wicks. The gravity stove tested with Pongamia pinnata (karanj) oil showed an efficiency of $11.81 \%$, and the kerosene stove was also tested using karanj oil which showed 5.65\% efficiency [18]. Previous studies reported that Jatropha oil can be blended with kerosene up to $30 \%$ for utilization in the pressure stove [6]. In the present study, a simple plant oil stove called the Jatrok stove was designed and manufactured in the workshop at the Ministry of Water, Irrigation, and Energy (MoWIE), and its performance and emission were tested and compared with the performance of domestic cooking stoves in Ethiopia. The thermal efficiency of domestic biomass cooking stoves such as the traditional wood stove, metal charcoal stove, and Laketch charcoal stove is $11.5 \%, 23 \%$, and $38 \%$, respectively [20]. The Tikikil wood stove has a thermal efficiency of $26 \%$. Ethanol and kerosene stoves have a thermal efficiency 56\% [21] and 60\% [22], respectively. The specific fuel consumption $(\mathrm{g} / \mathrm{l})$ of stoves such as the traditional wood stove, metal charcoal stove, and Laketch charcoal stove is $190 \mathrm{~g} / \mathrm{l}, 550 \mathrm{~g} / \mathrm{l}$, and $290 \mathrm{~g} / \mathrm{L}$, respectively [20]. Ethanol and kerosene stoves have a reduction in the specific fuel consumption from three-stone fire by $48 \%$ [21] and 4\% [22], respectively. The fire power (watts) of ethanol and kerosene stoves is $1200 \mathrm{~W}$ [21] and $1300 \mathrm{~W}$ [22], respectively. The emission of the traditional wood stove to boil 2.5 liters of water in Ethiopia is $92 \mathrm{~g} / \mathrm{l}$ and $681 \mathrm{~g} / \mathrm{l}$ of carbon monoxide and carbon dioxide, respectively. Lakech has carbon monoxide and carbon dioxide emission of $79 \mathrm{~g} / \mathrm{l}$ and $625 \mathrm{~g} / \mathrm{l}$, respectively, while Merchaye has $66 \mathrm{~g} / \mathrm{l}$ and $531 \mathrm{~g} / 1$ [23]. Ethanol has showed an emission of $2.12 \mathrm{~g} / \mathrm{l}$ and $175 \mathrm{~g} / \mathrm{l}$ of carbon monoxide and carbon dioxide, respectively [21].

The aim of this study is to investigate the effects of blending Jatropha oil with kerosene for cooking application. After studying the effects of heating and blending Jatropha with kerosene, the water boiling test was conducted to verify the possible use of the blend with various proportions.

\section{Materials and Methods}

In this study, Jatropha oil was extracted from dried Jatropha seeds using the Bielenberg ram oil press and purified through decantation. Blends of fuels were made by mixing Jatropha oil with kerosene. The viscosity of pure Jatropha and the blended fuels was measured by using the Brookfield DV2T viscometer, and calorific values were measured by using a calorimeter.

The materials used in this study were Jatropha oil, kerosene, the Brookfield DV2T, the Bielenberg ram oil press, balance, measuring cylinders, a calorimeter, a thermocouple, a hood system, a gas analyzer, aluminum pots, a stopwatch, and a data logger.

2.1. Development of the Plant Oil Stove. A simple plant oil stove was developed without wicks to solve problems associated to the difficulties of the plant oil going through wicks due to its high viscosity. To reduce the viscosity and improve the combustion of the oil, it was blended with kerosene. Since gravity plant stoves are not as such efficient [18] and pressures stoves are more complex and expensive, developing a simple and efficient stove for utilizing plant oils is of paramount importance. The stove designed for this study has 8 primary air holes with a diameter of $5 \mathrm{~mm}$ at $75 \mathrm{~mm}$ height of the stove. The total height of the stove is $155 \mathrm{~mm}$, and its pot seat has a $6 \mathrm{~mm}$ height with a combustion diameter of $110 \mathrm{~mm}$ (Figure 1). The plant oil stove was developed at the work shop of the Ministry of Water, Irrigation, and Energy of Ethiopia.

2.2. Extraction of Jatropha Oil. In the present study, the Bielenberg ram oil press was used to extract the oil from the seeds. First, the seeds were fed into the hopper and then, crushed and milled in the chamber. Furthermore, the shaft of the screw was rotated forward manually to open the gap, and thus, oil flowed through the oil outlet and the cake was pressed through the plates. After extraction, the Jatropha oil was allowed to settle and decanted to remove residues. Blends were prepared by mixing the oil and kerosene in four different proportions $(10: 90,20: 80,30: 70$, and $40: 60$ volume by volume ratios).

2.3. Viscosity Measurements. The viscosity of Jatropha oil was measured using the Brookfield viscometer model DV2T at temperatures of $20,30,40,50,60,70,80,90$, and $100^{\circ} \mathrm{C}$. For viscosity measurements, $300 \mathrm{~cm}^{3}$ of Jatropha oil was poured into a $600 \mathrm{~cm}^{3}$ volumetric glass, and a spindle was screwed into the viscometer. The cup containing the sample was carefully locked into position so that the spindle cone can be completely immersed in the sample. The machine was switched on, and readings of viscosity, torque, and speed of rotation of the spindles were observed after about ten seconds of rotation of the spindle in the container. Viscosity 

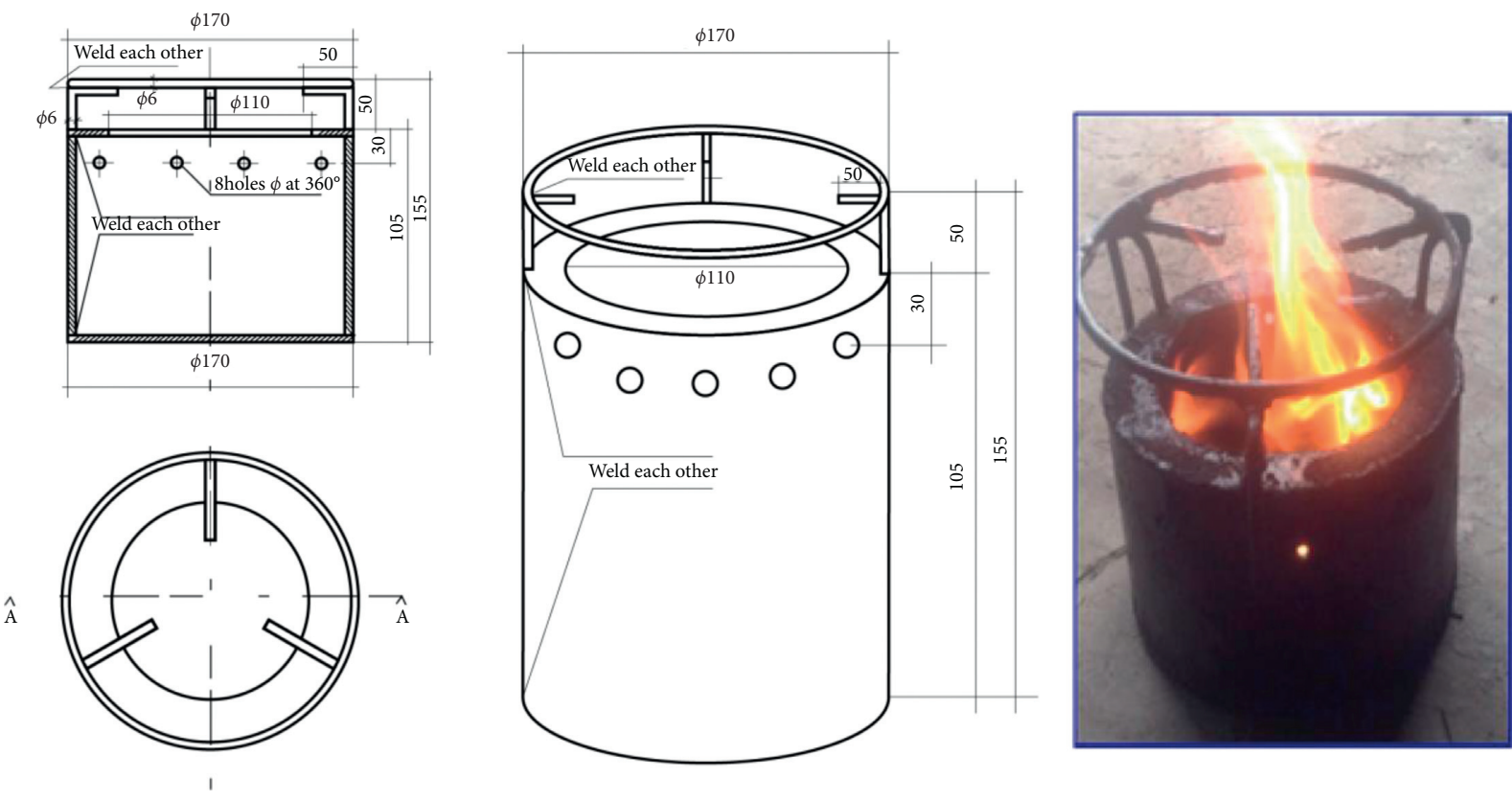

Figure 1: Design of the plant oil stove.

data were recorded when the torque was between $10 \%$ and $100 \%$. If the torque was out of these values, the spindle type or speed of rotation of the spindle was adjusted to correct the reading [24].

2.4. Calorific Value Measurements. The calorific value of a fuel is the theoretical maximum amount of energy extracted from the combustion of fuel in a calorimeter. A calorimeter is an apparatus used to measure the amount of heat involved in a chemical reaction. In determining calorific values of fuels, the fuel was measured and placed in the calorimeter bomb using capsules and the cotton tread was fastened on the fuse wire and touching the fuel in the capsule. The bomb was closed and filled with oxygen at a pressure of 30 bars. After putting the samples in the bomb and filling the oxygen gas, a water bucket was filled with $2000 \mathrm{ml}$ of water and inserted to the calorimeter jacket, and then, the bomb was inserted into the bucket. Finally, the calorimeter setting was turned on to start testing the calorific values of the fuel by combusting the fuel inside the bomb. The heating value was determined as the temperature rise in the water bucket [25].

$$
\begin{aligned}
& H_{c}=\frac{W * T-e_{1}-e_{2}-e_{3}}{m}, \\
& W=\frac{H * m+e_{4}+e_{5}+e_{6}}{T} .
\end{aligned}
$$

2.5. Performance Evaluation. The water boiling point test (cold and hot-start high power test) was conducted on the stove to determine the thermal efficiency, specific fuel consumption, and fire power of the stove using blended fuels in the cold-start high power phase. The test started with the stove at room temperature, using preweighted fuel (kerosene oil-blended fuels) to boil $2.5 \mathrm{~kg}$ water starting from room temperature. During the test, the ambient temperature and local boiling point were measured. The hot-start test followed a procedure same as that of the cold-start test, and the difference was that the hot-start test was started with a hot stove immediately after the cold-start test was completed. The thermocouple was inserted to the pot containing the water using a wooden fixture to measure the temperature. A hole was bored in the center of the wooden fixture to fit the thermocouple to the wooden fixture and prevent the water from escaping [26].

2.5.1. Thermal Efficiency. Thermal efficiency is a ratio of the work done by heating and evaporating water to the energy consumed by the burning fuel. It is an estimate of the total energy produced by the fire that is used to heat the water in the pot and calculated using the following equation [26]:

$$
\mathrm{Eff}=\frac{4.186 \mathrm{Ww}\left(T_{f}-T_{i}\right)+2260 * \mathrm{wV}}{f_{m} * \mathrm{LHV}} .
$$

2.5.2. Specific Fuel Consumption (SFC). Specific fuel consumption (SFC): SFC is the parameter that calculates the fuel required producing a unit output, and it is a measure of the fuel required to produce one liter of boiled water starting with cold stove and calculated using the following equation [26]:

$$
\text { SFC }(\mathrm{g} / \mathrm{L})=\frac{\text { mass of fuel }(\mathrm{g})}{\text { mass of boild water }(\mathrm{L})} \text {. }
$$

2.5.3. Fire Power. Fire power is a measure of fuel energy consumed to boil the water divided by the time to boil, and it 
tells the average power output of the stove in watts [19]. The fire power of the stove is calculated using the following equation [26]:

Fire power $(\mathrm{W})=($ Mass of fuel $(\mathrm{kg}) \times \mathrm{LHV}) /$ Time $($ second. $)$.

2.5.4. Emission Testing. The emission of the stove was collected in the emission hood, and it was calculated using the hood carbon balance method. Data on $\mathrm{CO}_{2}$ and $\mathrm{CO}$ emissions were collected to boil 2.5 liter water following standard water boiling test method [26]. The hood method was used for determining the emissions with a Testo 330-LL flue gas analyzer [27]. The analyzer has an accuracy of $\pm 20 \mathrm{ppm} \mathrm{CO}$ with a measuring range 0 to $4000 \mathrm{ppm} \mathrm{CO}$ and $1 \mathrm{ppm}$ resolution, with a reaction time of approximately 40 seconds, and a measuring range $0-10,000 \mathrm{ppm}$ and $1 \mathrm{ppm}$ resolution, with a reaction time of 90 minutes for $\mathrm{CO}_{2}$.

$$
\text { Emission }(\mathrm{g} / \mathrm{kg})=\frac{\text { Dry fuel collected in emissions }}{\text { Dry fuel consumed }} \text {. }
$$

2.6. Statistical Analysis. The statistical analysis for the mean differences in viscosity, thermal efficiency, specific fuel consumption, and fire power of the Jatrok stove was performed using the $T$-test at $5 \%$ level of significance in SPSS statistical software version 20 . The carbon monoxide and carbon dioxide data were analyzed using descriptive analysis.

2.7. Experimental Setup. The performance and emission test of the newly developed Jatrok stove using blended fuels were performed using water boiling test protocol. The stove tested was placed under a hood, and the gas analyzer probe was inserted into the hood so that emissions are automatically collected and analyzed by the instrument. Figure 2 shows the experimental setup for conducting the test.

\section{Results}

3.1. Effect of Temperature on the Viscosity of Jatropha Oil. Previous studies showed that many vegetable oils' viscosity is reduced on heating [9]. In the present investigation, the Jatropha oil viscosity was tested in temperatures ranging from $20^{\circ} \mathrm{C}$ to $100^{\circ} \mathrm{C}$. The results showed that the viscosity of Jatropha oil reduced on heating. The viscosity of Jatropha oil at $20^{\circ} \mathrm{C}$ was between 42 and $46 \mathrm{cSt}$, and its viscosity at $100^{\circ} \mathrm{C}$ became 4.7 to $7 \mathrm{cSt}$ with a 95\% level of confidence (Table 1). The viscosity of Jatropha oil was reduced by $86.3 \%$ when the temperature increased from $20^{\circ} \mathrm{C}$ to $100^{\circ} \mathrm{C}$.

An exponential decreasing relationship exists between viscosity and temperature showing functional dependence of viscosity on temperature. Figure 3 shows the regression coefficient value, $\left(R^{2}\right)$, for temperature-viscosity relationships of 0.9466 , which indicates that $94.66 \%$ of the total variation in the viscosity reduction is attributed to temperature.
3.2. Viscosities of Blended Fuels. Studies reported that blending of vegetable oil with other fuels such as alcohol or diesel fuel reduced the viscosity of vegetable oil [24]. In the present study, the Jatropha oil and kerosene were blended as $\mathrm{J} 10, \mathrm{~J} 20, \mathrm{~J} 30$, and J40, and their viscosity were measured and analyzed. The viscosity of Jatropha oil at room temperature (44 cSt) was taken as the baseline for comparing the effect of blending with kerosene on the viscosity of Jatropha oil. The viscosity of Jatropha oil reduced by $65 \%$ at $40 \%$ Jatropha oil in the blend and by $89 \%$ at $10 \%$ in the blend when compared with the viscosity of Jatropha at $20^{\circ} \mathrm{C}$. The viscosity of the J10 (10\% Jatropha- and $90 \%$ kerosene-blended fuel) was between 3.9609 and $5.7057 \mathrm{cSt}$ and that of J40 (40\% Jatropha oil and $60 \%$ kerosene blend fuel) was between 13.45 and $17.21 \mathrm{cSt}$ with a $95 \%$ confidence level (Table 3).

The regression analysis indicates that the effect of blending Jatropha oil with kerosene on Jatropha oil viscosity was significant. The regression coefficient $\left(R^{2}\right)$ value was 0.9479 indicating that $94.79 \%$ of the variation in the viscosity of the Jatropha oil is attributed to blending (Figure 4).

3.3. Calorific Value of Blended Fuels. The calorific values of the blended fuels were determined by following calorific value determination of combustible fuels steps described by the parr 6200 calorimeter (Table 5).

\subsection{Stove Performance Testing}

3.4.1. Thermal Efficiency. The thermal efficiency of the stove with J10, J20, and J40 fuel was $66 \%, 56 \%$, and $52 \%$, respectively (Tables 6-8). The reason for lower thermal efficiency with increased Jatropha oil in the blend was due to higher viscosity, poor volatility, and low combustibility of the oil.

3.4.2. The Specific Fuel Consumption. The specific fuel consumption of the stove increased with increasing Jatropha oil in the blend due to its low combustibility, and the specific fuel consumption of the stove with J10, J20, and J40 fuels was $30 \mathrm{~g} / \mathrm{L}, 35 \mathrm{~g} / \mathrm{L}$, and $38 \mathrm{~g} / \mathrm{L}$, respectively (Tables $6-8$ ). The lower combustion resulted in more consumption of the fuel to generate enough heat. Increasing the oil ratio in the blend caused low combustion due to poor volatility and lower ability of the fuel to mix with oxygen.

3.4.3. Fire Power. The fire power of the Jatrok stove decreased with increasing Jatropha oil in the blend. The fire power of the stove with J10, J20, and J40 blended fuels was $1433 \mathrm{~W}, 1404 \mathrm{~W}$, and $1399 \mathrm{~W}$, respectively (Tables 6-8). The reason for reducing the fire power as the oil ratio increased in the blend was the explanation same as that given above for the fuel consumption. Fire power is the fuel energy consumed to complete some task, such as cooking divided by the time it takes to cook. As the combustion of the fuel reduced, enough energy could not be generated and the rate of energy delivered to the stove is reduced. In this study, as the Jatropha oil increased in the blend, the rate of energy 


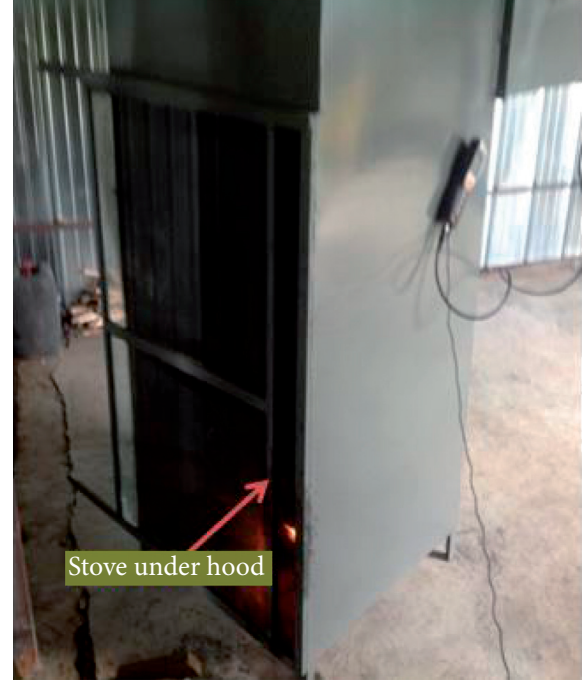

(a)

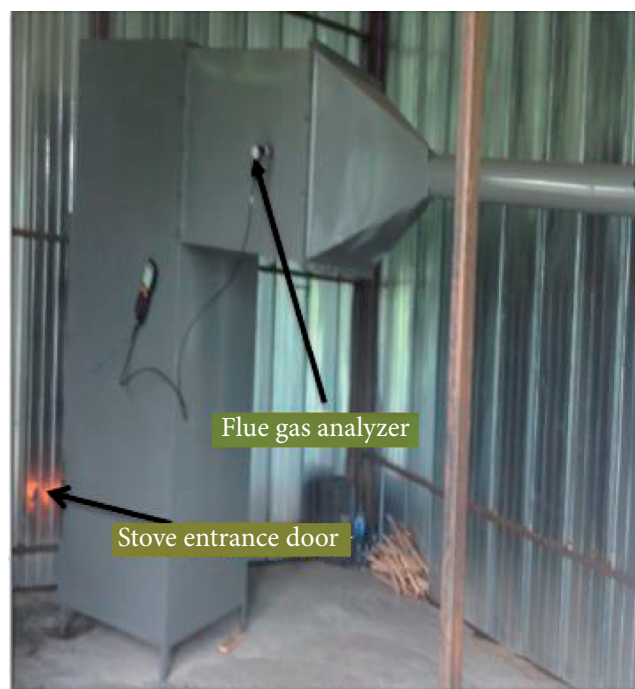

(b)

FIGURE 2: Hood-type experimental setup for stove testing.

TABLe 1: The change in viscosity of Jatropha oil with temperature increment.

\begin{tabular}{|c|c|c|c|c|c|c|c|c|c|c|}
\hline \multirow{3}{*}{$\begin{array}{l}\text { Temp } \\
\text { (oc) }\end{array}$} & \multirow{3}{*}{ Test 1} & \multirow{3}{*}{ Test 2} & \multirow{3}{*}{ Test 3} & \multirow{3}{*}{ Mean } & \multicolumn{4}{|c|}{ Viscosity (cSt) } & \multirow{2}{*}{\multicolumn{2}{|c|}{$\begin{array}{c}\text { 95\% confidence } \\
\text { level }\end{array}$}} \\
\hline & & & & & \multirow[t]{2}{*}{$\mathrm{SD}$} & \multirow[t]{2}{*}{ Std. error } & \multirow{2}{*}{$\begin{array}{c}T- \\
\text { test }\end{array}$} & \multirow[t]{2}{*}{$P$ value } & & \\
\hline & & & & & & & & & Lower & Upper \\
\hline 20 & 45 & 43.5 & 44 & 44 & 0.76 & 0.44 & 100 & 0.001 & 42.26 & 46.06 \\
\hline 30 & 43 & 41.5 & 42 & 42 & 0.76 & 0.440 & 95.6 & 0.001 & 40.26 & 44.06 \\
\hline 40 & 36.5 & 37.2 & 38.5 & 37.5 & 1.01 & 0.58 & 63.8 & 0.001 & 34.87 & 39.92 \\
\hline 50 & 29.5 & 31.5 & 29.5 & 30 & 1.15 & 1.66 & 45.2 & 0.001 & 27.3 & 33.03 \\
\hline 60 & 23 & 25.5 & 26.5 & 25 & 1.80 & 1.04 & 24.0 & 0.002 & 20.52 & 29.47 \\
\hline 70 & 18 & 19.5 & 17.85 & 18.5 & 0.91 & 1.52 & 35.0 & 0.001 & 16.18 & 20.71 \\
\hline 80 & 13 & 14 & 13.5 & 13.5 & 0.5 & 1.28 & 46.7 & 0.001 & 12.25 & 14.74 \\
\hline 90 & 10 & 11 & 10.5 & 10.5 & 0.5 & 1.28 & 36.3 & 0.001 & 9.25 & 11.74 \\
\hline 100 & 5.5 & 6 & 6.5 & 6.0 & 0.5 & 1.28 & 20.7 & 0.002 & 4.75 & 7.24 \\
\hline
\end{tabular}

The overall viscosity reduction by heating was statistically significant as tested by the $T$-test $(P<0.001)$ (Table 2 ).

TABLE 2: Statistical test of viscosity of Jatropha oil and temperature.

\begin{tabular}{lcccc}
\hline & $T$-test & $P$ value & Std. error mean & Std. deviation \\
\hline Viscosity & 5.39 & 0.001 & 4.68 & 14.04 \\
Temperature & 6.58 & 0.001 & 9.12 & 27.38 \\
\hline
\end{tabular}

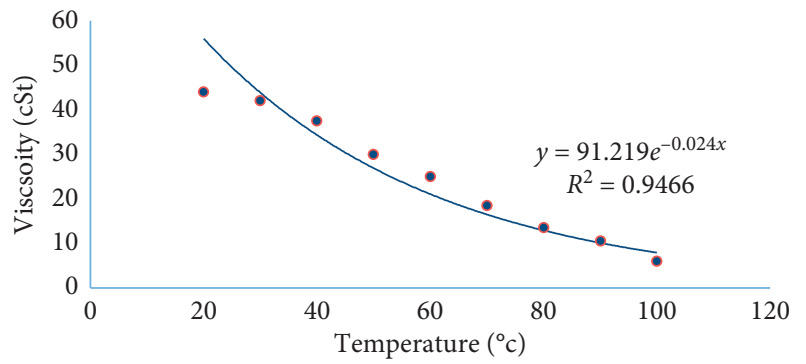

FIGURE 3: Approximate graph for the temperature-viscosity relationship. delivered to the stove was reduced due to the oil's low combustibility.

3.5. Emission Test Results of the Jatrok Stove Using Blended Fuels. The carbon monoxide and carbon dioxide emissions of the Jatrok stove were measured during the cold-start high power test of the water boiling test procedure, and the results are presented in Table 9. CO emissions of the Jatrok stove were $11.5 \mathrm{~g} / \mathrm{L}, 11.3 \mathrm{~g} / \mathrm{L}$, and $9.5 \mathrm{~g} / \mathrm{L}$ using J10, J20, and J40 fuels, respectively (Table 9), and its $\mathrm{CO}_{2}$ emissions were $352 \mathrm{~g} / \mathrm{L}, 334 \mathrm{~g} / \mathrm{L}$, and $289.2 \mathrm{~g} / \mathrm{L}$ using J10-, J20-, and J40blended fuels, respectively (Table 9 ).

\section{Discussion}

The viscosity of vegetable oils (avocado, canola, rapeseed, macadamia nut, olive, peanut, rice bran, safflower, sunflower, and soybean) has been shown to reduce on heating [9]. The viscosity of the oil was reduced by $86.3 \%$ when the 
TABLE 3: Effect of blending on the viscosity of the Jatropha oil.

\begin{tabular}{|c|c|c|c|c|c|c|c|c|c|c|}
\hline \multirow{3}{*}{ Fuel } & \multicolumn{10}{|c|}{ Viscosity (cSt) } \\
\hline & \multirow[t]{2}{*}{ Test 1} & \multirow[t]{2}{*}{ Test 2} & \multirow[t]{2}{*}{ Test 3} & \multirow[t]{2}{*}{ Ave. } & \multirow[t]{2}{*}{$\mathrm{SD}$} & \multirow[t]{2}{*}{ Std. error } & \multirow[t]{2}{*}{$T$-test } & \multirow[t]{2}{*}{$P$ value } & \multicolumn{2}{|c|}{$\begin{array}{c}\text { 95\% confidence } \\
\text { level }\end{array}$} \\
\hline & & & & & & & & & Lower & Upper \\
\hline $\mathrm{J} 100$ & 45 & 43.5 & 44 & 44.2 & 0.50 & 0.28 & 129.9 & 0.001 & 36.2 & 38.7 \\
\hline $\mathrm{J} 10$ & 4.8 & 5.2 & 4.5 & 4.8 & 0.35 & 0.20 & 23.83 & 0.002 & 3.96 & 5.70 \\
\hline $\mathrm{J} 20$ & 7.8 & 8.5 & 7.5 & 7.9 & 0.51 & 0.29 & 26.77 & 0.001 & 6.65 & 9.20 \\
\hline $\mathrm{J} 30$ & 13.5 & 12.8 & 13.5 & 13.2 & 0.40 & 0.23 & 56.85 & 0.001 & 12.2 & 14.27 \\
\hline $\mathrm{J} 40$ & 14.8 & 16.2 & 15 & 15.3 & 0.75 & 0.43 & 35.07 & 0.001 & 13.45 & 17.21 \\
\hline
\end{tabular}

Viscosity of Jatropha oil showed a statistically significant reduction due to blending with kerosene fuel $(P<0.023)$ (Table 4$)$.

TABLE 4: Statistical test of the effect of blending on Jatropha oil viscosity.

\begin{tabular}{lccccc}
\hline & T-test & $P$ value & Std. error mean & std. deviation & $\begin{array}{c}95 \% \text { confidence interval } \\
\text { of the difference } \\
\text { Upper }\end{array}$ \\
\hline Fuel type & & & 6.45 & 12.90 & 4.55 \\
Viscosity (cSt) & 3.87 & 0.030 & 2.40 & 4.81 & 0.44 \\
\hline
\end{tabular}

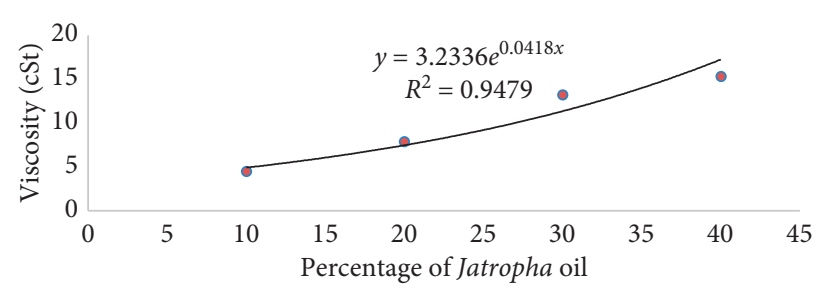

FIGURE 4: Effect of blending of kerosene on the viscosity of Jatropha oil.

TABLE 5: Calorific values of blended fuels.

\begin{tabular}{lccccc}
\hline \multirow{2}{*}{ Fuel } & \multicolumn{5}{c}{ Calorific values $(\mathrm{kJ} / \mathrm{kg})$} \\
& Test 1 & Test 2 & Test 3 & Ave. & Mean \\
\hline J10 & 42925 & 43225 & 42559 & 42903 & 42903 \\
J20 & 42312 & 41985 & 42703 & 42333 & 42333 \\
J40 & 41863 & 40803 & 40860 & 41175 & 41175 \\
\hline
\end{tabular}

TABLE 6: Performance of the Jatrok stove using J10 fuel.

\begin{tabular}{|c|c|c|c|c|c|c|c|c|c|c|c|}
\hline \multirow{2}{*}{ Parameters } & \multicolumn{6}{|c|}{ High power (cold-start test result) } & \multicolumn{5}{|c|}{ High power (hot-start test result) } \\
\hline & Units & Test 1 & Test 2 & Test 3 & Mean & Stdv. & Test 1 & Test 2 & Test 3 & Mean & Stdv. \\
\hline Time to boil & Min & 31 & 30 & 35 & 32 & 2.6 & 26 & 29 & 28 & 27.7 & 1.52 \\
\hline Temp-corrected time to boil & Min & 31 & 30 & 35 & 32 & 2.6 & 27 & 29 & 29 & 28.3 & 1.15 \\
\hline Burning rate & $\mathrm{g} / \mathrm{min}$ & 2 & 2 & 2 & 2 & 0 & 2 & 2 & 2 & 2.2 & 0 \\
\hline Thermal efficiency & $\%$ & $65 \%$ & $69 \%$ & $59 \%$ & $65 \%$ & $5 \%$ & $69 \%$ & $68 \%$ & $63 \%$ & $66 \%$ & $3 \%$ \\
\hline Specific fuel consumption & g/liter & 31 & 28 & 32 & 30.3 & 2.1 & 29 & 29 & 31 & 29.7 & 1.15 \\
\hline Temp-corrected specific fuel consumption & g/liter & 31 & 28 & 32 & 30.3 & 2.08 & 30 & 29 & 32 & 30.3 & 1.52 \\
\hline Temp-corrected specific energy cons. & $\mathrm{kJ} / \mathrm{liter}$ & 1,259 & 1,164 & 1,291 & 1238 & $66 \%$ & 1,190 & 1,207 & 1,289 & 1228.7 & 53 \\
\hline Fire power & Watts & 1,398 & 1,357 & 1,276 & 1344 & 62 & 1,538 & 1,452 & 1,571 & 1521 & 61 \\
\hline
\end{tabular}


TABle 7: Performance of the Jatrok stove using J20 fuel.

\begin{tabular}{|c|c|c|c|c|c|c|c|c|c|c|c|}
\hline \multirow{2}{*}{ Parameters } & \multicolumn{6}{|c|}{ High power (cold-start test results) } & \multicolumn{5}{|c|}{ High power (hot-start test results) } \\
\hline & Units & Test 1 & Test 2 & Test 3 & Mean & Stdv. & Test 1 & Test 2 & Test 3 & Mean & Stdv. \\
\hline Time to boil & Min & 42 & 36 & 38 & 38.7 & 3.1 & 30 & 34 & 32 & 32 & 2 \\
\hline Temp-corrected time to boil & Min & 42 & 36 & 39 & 38.7 & 3.2 & 31 & 34 & 33 & 32.4 & 1.4 \\
\hline Burning rate & $\mathrm{g} / \mathrm{min}$ & 2 & 2 & 2 & 1.9 & 0.2 & 3 & 2 & 2 & 2.3 & 0.2 \\
\hline Thermal efficiency & $\%$ & $57 \%$ & $53 \%$ & $55 \%$ & $55 \%$ & $2 \%$ & $55 \%$ & $55 \%$ & $59 \%$ & $56 \%$ & $2 \%$ \\
\hline Specific fuel consumption & g/liter & 33 & 34 & 36 & 34.4 & 1.4 & 36 & 35 & 32 & 34.3 & 1.9 \\
\hline Temp-corrected specific consumption & g/liter & 33 & 34 & 37 & 34.6 & 1.8 & 37 & 35 & 33 & 35.1 & 1.9 \\
\hline Temp-corrected specific energy cons. & $\mathrm{kJ} / \mathrm{liter}$ & 1,330 & 1,414 & 1,460 & 1401.3 & 65.8 & 1486 & 1468 & 1335 & 1429.6 & 82.8 \\
\hline Fire power & Watts & 1,111 & 1,403 & 1,316 & 1277 & 150.0 & 1667 & 1507 & 1417 & 1530 & 126.6 \\
\hline
\end{tabular}

TABle 8: Performance of the Jatrok stove using J40 fuel.

\begin{tabular}{|c|c|c|c|c|c|c|c|c|c|c|c|}
\hline & \multicolumn{6}{|c|}{ High power (cold-start test results) } & \multicolumn{5}{|c|}{ High power (hot-start test results) } \\
\hline & Units & Test 1 & Test 2 & Test 3 & Mean & Stdv. & Test 1 & Test 2 & Test 3 & Mean & Stdv \\
\hline Time to boil & $\min$ & 38 & 40 & 35 & 37.7 & 2.5 & 40 & 41 & 35 & 38.7 & 3.2 \\
\hline Temp-corrected time to boil & $\min$ & 38 & 39 & 35 & 37.6 & 2 & 41 & 40 & 36 & 39.3 & 2.8 \\
\hline Burning rate & $\mathrm{g} / \mathrm{min}$ & 2 & 2 & 2 & 2.1 & 0.3 & 2 & 2 & 2 & 2 & 0.2 \\
\hline Thermal efficiency & $\%$ & 52 & 53 & 47 & 51 & 3 & 54 & 50 & 51 & 52 & 2 \\
\hline Specific fuel consumption & g/liter & 38 & 36 & 40 & 38.3 & 2.2 & 36 & 37 & 36 & 36.3 & 0.6 \\
\hline Temp-corrected specific consumption & g/liter & 38 & 36 & 41 & 38.3 & 2.7 & 37 & 37 & 37 & 37 & 0.3 \\
\hline Temp-corrected specific energy cons. & $\mathrm{kJ} /$ liter & 1535 & 1498 & 1642 & 1558.1 & 74.6 & 1479 & 1547 & 1497 & 1507.6 & 35.1 \\
\hline Fire power & watts & 1404 & 1316 & 1619 & 1446 & 156.1 & 1250 & 1335 & 1467 & 1351 & 109.2 \\
\hline
\end{tabular}

TABLe 9: Emission test result of the Jatrok stove using blended fuels.

\begin{tabular}{|c|c|c|c|c|c|c|}
\hline Fuel & Parameters & Test 1 & Test 2 & Test 3 & Mean & Stdv. \\
\hline \multirow{5}{*}{ J10K90 } & $\mathrm{CO}(\mathrm{ppm})$ & 368 & 378 & 298 & 348 & 43.5 \\
\hline & $\mathrm{CO}_{2}(\mathrm{ppm})$ & 9700 & 10900 & 12500 & 11033 & 1404.7 \\
\hline & Fuel consumed (gm) & 77.5 & 70 & 80 & 75.8 & 5.2 \\
\hline & CO emission $(\mathrm{g} / \mathrm{kg})$ & 11.8 & 13.5 & 9.3 & 11.5 & 2.1 \\
\hline & $\mathrm{CO}_{2}$ emission $(\mathrm{g} / \mathrm{kg})$ & 313 & 352 & 391 & 352 & 39 \\
\hline \multirow{5}{*}{$\mathrm{J} 20 \mathrm{~K} 80$} & $\mathrm{CO}(\mathrm{ppm})$ & 478 & 362 & 326 & 388.6 & 79.4 \\
\hline & $\mathrm{CO}_{2}(\mathrm{ppm})$ & 13500 & 10700 & 10300 & 11500 & 1743.5 \\
\hline & Fuel consumed (gm) & 82.5 & 85 & 92.5 & 86.6 & 5.2 \\
\hline & $\mathrm{CO}$ emission $(\mathrm{g} / \mathrm{kg})$ & 14.5 & 10.6 & 8.8 & 11.3 & 2.9 \\
\hline & $\mathrm{CO}_{2}$ emission $(\mathrm{g} / \mathrm{kg})$ & 409 & 314.7 & 278.3 & 334 & 67.4 \\
\hline \multirow{5}{*}{ J40K60 } & $\mathrm{CO}(\mathrm{ppm})$ & 429 & 341 & 307 & 359 & 62.9 \\
\hline & $\mathrm{CO}_{2}(\mathrm{ppm})$ & 12300 & 11400 & 9100 & 10933 & 1650 \\
\hline & Fuel consumed (gm) & 95 & 90 & 100 & 95 & 5 \\
\hline & $\mathrm{CO}$ emission $(\mathrm{g} / \mathrm{kg}))$ & 11.3 & 9.5 & 7.7 & 9.5 & 1.8 \\
\hline & $\mathrm{CO}_{2}$ emission $(\mathrm{g} / \mathrm{kg})$ & 323.7 & 316.8 & 227.5 & 289.2 & 53.6 \\
\hline
\end{tabular}

temperature increased from $20^{\circ} \mathrm{C}$ to $100^{\circ} \mathrm{C}$. The viscosity of Jatropha oil reduced by $65 \%$ and $89 \%$ at $40 \%$ and $10 \%$ oil, respectively, compared to the oil's viscosity at $20^{\circ} \mathrm{C}$. In the present study, the viscosity of Jatropha oil reduced significantly on heating. This exponential decreasing pattern in viscosity with increasing temperature is similar with Eryilmaz and Yesilyurt's [8] research on safflower oil-diesel research.

The Jatrok stove was compared with the previous works on the cookstoves in terms of thermal efficiency, specific fuel consumption, and fire power and emission characteristics of the stoves. The thermal efficiency of the Jatrok stove using J10, J20, and J40 fuels was of $66 \%, 56 \%$, and $52 \%$, respectively. The stove using up to $40 \%$ Jatropha oil is more efficient than the thermal efficiency of the traditional stove [20], metal charcoal stove [20], Lakech [20], and rocket stoves [20] and comparable with the thermal efficiency of ethanol [21] and kerosene stoves [22]. The conventional kerosene and gravity stoves with plant oil (karanj) have a thermal efficiency of $5.65 \%$ and $11.81 \%$, respectively [18]. In the present study, the Jatrok stove using blended fuels up to $40 \%$ oil has thermal efficiencies more than $50 \%$. The specific fuel consumption of the Jatrok stove using J10, J20, and J40 is less than that of the traditional stove [20], metal stove [20], Lakech [20], rocket [20], and ethanol stove [21]; however, it is more than that of the kerosene stove [22]. The fire power of the Jatrok stove power using J10, J20, and J40 fuels was comparable with the fire power of the ethanol stove [21] and kerosene stove [22]. CO and $\mathrm{CO}_{2}$ emissions of the Jatrok stove using J10, J20, and J40 are comparable with the CO emission of the ethanol stove [21] but much less than that of the traditional [23], Lakech, and Merchaye cookstoves [23]. In addition, $\mathrm{CO}$ emission decreases when 
increasing the percentage of blending Jatropha oil with kerosene, and this is similar with the decreasing trend seen when blending biodiesel with diesel fuel [12-17].

\section{Conclusions}

In this study, effects of temperature and blending of the Jatropha oil with kerosene on the viscosity of Jatropha oil were investigated. The results showed that viscosity of Jatropha oil is significantly reduced on heating and blending with kerosene. In addition, the Jatrok plant stove using Jatropha- and kerosene-blended fuel was also investigated in this study to see its effect on the stove performance on this blended fuel. A summary of the study is presented below:

The viscosity of Jatropha oil was reduced by $86.3 \%$ when the temperature increased from $20^{\circ} \mathrm{C}$ to $100^{\circ} \mathrm{C}$. This is the effect of temperature on Jatropha oil.

When blending 40\% Jatropha oil with kerosene, the viscosity of the blend reduced by $65 \%$. At $10 \%$ Jatropha oil blend, the viscosity reduced by $89 \%$. This makes the reduction in viscosity suitable for the cooking stove.

The calorific value reduced as the blending increased from 10\% Jatropha to 40\% Jatropha from 42,903 kJ/kg to $41,175 \mathrm{~kJ} / \mathrm{kg}$.

The stove performance indicators, thermal efficiency, specific fuel consumption, and fire power, were investigated to understand the effect of blending Jatropha oil with kerosene. The thermal efficiency decreased from $66 \%$ to $52 \%$ when the Jatropha oil blend increased from $10 \%$ to $40 \%$. The specific fuel consumption increased from $30 \mathrm{~g} / \mathrm{L}$ to $38 \mathrm{~g} / \mathrm{L}$ when blending Jatropha oil from $10 \%$ to $40 \%$. The fire power of the stove reduced from $1433 \mathrm{~W}$ to $1399 \mathrm{~W}$ when Jatropha oil was blended in the ratio of $10 \%$ to $40 \%$ with kerosene. The reduction in the stove performance is not much compared to the price of kerosene in the rural area.

The carbon monoxide and carbon dioxide emissions of the stove when using blended Jatropha oil with kerosene from $10 \%$ to $40 \%$ Jatrohpa oil was a CO emission reduction from $11.5 \mathrm{~g} / \mathrm{L}$ to $9.5 \mathrm{~g} / \mathrm{L}$. In the case of carbon dioxide, it was reducing from $352 \mathrm{~g} / \mathrm{L}$ to $289 \mathrm{~g} / \mathrm{L}$. The reduction in carbon monoxide has a reduction in indoor air pollution load in the kitchen.

The abovementioned conclusion suggests that Jatropha oil blended with kerosene could be an alternative fuel for biomass cooking stoves replacing the poor efficiency stoves in the rural areas.

\section{Nomenclature}

\section{cSt: $\quad$ Centistokes}

$e_{1}$ : Heat produced by burning the nitrogen portion of the air trapped in the bomb to form nitric acid

$e_{2}$ : Heat produced by the formation of sulfuric acid from the reaction of sulfur dioxide, water, and oxygen

$e_{3}$ : Heat produced by the heating wire and cotton thread $e_{4}$ : Correction for the heat of formation of nitric acid $(\mathrm{kJ} /$ $\mathrm{kg})$

$e_{5}$ : Correction for sulfur which is usually 0

$e_{6}$ : Correction for heating wire and combustion of the cotton thread $(\mathrm{kJ} / \mathrm{kg})$

Eff: Thermal efficiency (\%)

$f_{m}: \quad$ Fuel consumed $(\mathrm{g})$

$H$ : $\quad$ Heat of combustion of the standard benzoic acid sample $(\mathrm{kJ} / \mathrm{kg})$

$H_{c}$ : Gross heat of combustion

LHV: Lower heating value for the fuel $(\mathrm{J} / \mathrm{kg})$

M: $\quad$ Mass of the sample (g)

SFC: Specific fuel consumption (g/L)

$\mathrm{T}$ : Temperature rise

$T_{i}, T_{f}$ : Initial and final temperature $\left({ }^{\circ} \mathrm{C}\right)$

W: Energy equivalent of the calorimeter being used

wv: Water vaporized from the pot $(\mathrm{g})$

Ww: Mass of water remaining in the pot $(\mathrm{g})$.

\section{Data Availability}

The raw and analyzed data can be obtained on reasonable request from the authors.

\section{Conflicts of Interest}

The authors declare that they have no conflicts of interest regarding the publication of this paper.

\section{Acknowledgments}

This research was funded by the MRV program at Wondo Genet College of Forestry and Natural Resources, Hawassa University. The authors would like to thank the Ministry of Water, Irrigation, and Energy (MWIE) of Ethiopia for permitting them to use the laboratory and workshop facility to conduct the tests.

\section{References}

[1] A. Birhanu and S. Ayalew, "A review on potential and status of biofuel production in Ethiopia," Jounral of Plant Sciences, vol. 5, no. 2, pp. 82-89, 2017.

[2] MoME, A Review on Potential and Status of Biofuel Production in Ethiopia, pp. 1-16, 2007.

[3] K. Hammer and J. Heller, "Physic nut Jatropha curcas: promoting the conservation and use of underutilized and neglected crops," Economic Botangy, vol. 52, no. 1, p. 77, 1996.

[4] K. Ahmed, "Developing, testing and promotion of small scale Jatropha and Castor seed processing technologies," International Journal of Technology Enhancements and Emerging Engineering Research, vol. 1, no. 3, pp. 28-34, 2013.

[5] M. Asmare and N. Gabbiye, "Synthesis and characterization of biodiesel from castor bean as alternative fuel for diesel engine," American Journal of Energy Engineering, vol. 2, no. 1, pp. 1-15, 2014.

[6] A. Yadav and P. C. Jha, "A case study on biofuel stove technology: Jatropha as a biofuel," International Journal of Technology Enhancements and Emerging Engineering Research, vol. 1, no. 2, pp. 14-18, 2013. 
[7] B. Prbakaran and D. Viswanathan, "Experimental investigation of effects of addition of ethanol to bio-diesel on performance, combustion and emission characteristics in CI engine," Alexandria Engineering Journal, vol. 57, no. 1, pp. 383-389, 2018.

[8] T. Eryilmaz and M. K. Yesilyurt, "Influence of blending ratio on the physicochemical properties of safflower oil methyl ester-safflower oil, safflower oil methyl ester-diesel and safflower oil-diesel," Renewable Energy, vol. 95, pp. 233-247, 2016.

[9] L. M. Diamante and T. Lan, “Absolute viscosities of vegetable oils at different temperatures and shear rate range of 64.5 to 4835 s-1," Journal of Food Processing, vol. 2014, Article ID 234583, 6 pages, 2014.

[10] H. Fukuda, A. Kondo, and H. Noda, "Biodiesel fuel production by transesterification of oils," Journal of Bioscience and Bioengineering, vol. 92, no. 5, pp. 405-416, 2001.

[11] W. M. J. Achten, L. Verchot, Y. J. Franken et al., "Jatropha biodiesel production and use," Biomass and Bioenergy, vol. 32, no. 12, pp. 1063-1084, 2008.

[12] U. Rajak, P. Nashine, and T. N. Verma, "Effect of spirulina microalgae biodiesel enriched with diesel fuel on performance and emission characteristics of CI engine," Fuel, vol. 268, Article ID 117305, 2020.

[13] N. Krishania, U. Rajak, P. K. Chaurasiya, T. S. Singh, A. K. Birru, and T. N. Verma, "Investigations of spirulina, waste cooking and animal fats blended biodiesel fuel on autoignition diesel engine performance, emission characteristics," Fuel, vol. 276, Article ID 118123, 2020.

[14] M. K. Yesilyurt, Z. Yilbasi, and M. Aydin, "The performance, emissions, and combustion characteristics of an unmodified diesel engine running on the ternary blends of pentanol/ safflower oil biodiesel/diesel fuel," Journal of Thermal Analysis and Calorimetry, vol. 140, no. 6, pp. 2903-2942, 2020.

[15] U. Rajak, P. Nashine, and T. Nath Verma, "Numerical study on emission characteristics of a diesel engine fuelled with diesel-spirulina microalgae-ethanol blends at various operating conditions," Fuel, vol. 262, Article ID 116519, 2020.

[16] U. Rajak, P. Nashine, and T. N. Verma, "Characteristics of microalgae spirulina biodiesel with the impact of n-butanol addition on a CI engine," Energy, vol. 189, Article ID 116311, 2019.

[17] U. Rajak, P. Nashine, T. N. Verma, and A. Pugazhendhi, "Performance, combustion and emission analysis of microalgae Spirulina in a common rail direct injection diesel engine," Fuel, vol. 255, Article ID 115855, 2019.

[18] P. K. Halder, M. U. H. Joardder, M. R. A. Beg, N. Paul, and I. Ullah, "Utilization of bio-oil for cooking and lighting," Advances in Mechanical Engineering, vol. 4, Article ID 190518, 2012.

[19] K. Martin, E. Stumpf, and J. Muller, "Development of a plant oil pressure stove," in Conference on International Agricultural Research for Development, University of Kassel-Witzenhausen and University of Gottingen Germany, Göttingen, Germany, 2007.

[20] Ethiopia, Stove Test Results Ethiopia ECO. 2019, https:// energypedia.info/images/f/f9/Stove_testing_results_ summary.pdf.

[21] J. J. Jetter and S. Ebersviller, Test Report on Clean Cook Model A1 Stove with Alcholol Fuel: Air Pollutant Emissions and Fuel Efficiency, U.S. Environmental Protection Agency, Washington, DC, USA, 2015.

[22] M. D. Masekameni, T. Makonese, and H. J. Annegarn, "A comparison of emissions and thermal efficiency of three improved liquid fuel stoves," in Proceedings of the 2015 International Conference on the Domestic Use of Energy (DUE), Cape Town, South Africa, March 2015.

[23] F. Mamuye, B. Lemma, and T. Woldeamanuel, "Emissions and fuel use performance of two improved stoves and determinants of their adoption in Dodola, southeastern Ethiopia," Sustainable Environment Research, vol. 28, no. 1, pp. 32-38, 2018.

[24] B. Ametek, More Solutions to Sticky Prolems: A Guide to Getting More from Your Brookfield Viscometer \& Rheometer, Brookfield Engineering, Middleborough, MA, USA, 2017, https://www.brookfieldengineering.com/-/media/ ametekbrookfield/tech\%20sheets/more\%20solutions\% 202017.pdf?la=en.

[25] Beckman Coulter, Oxygen Bomb Calorimeter (Parr 6300 Calorimeter), Beckman Coulter, Brea, CA, USA, 2011.

[26] WBT, "The water boiling test version 4.2.3," in Cookstove Emissions and Efficiency in a Controlled Laboratory Setting, Global Alliance for Clean Cookstoves, Washington, DC, USA, 2014.

[27] Testo, Testo 330-LL Flue Gas Analyzer, Fotronic Corporation \& 5 Commonwealth Ave, Woburn, MA, USA, 2016, https:// static-int.testo.com/media/19/b2/9d1cfff0a18c/testo-330_ Instruction-Manual.pdf. 